$\mathrm{PhD}$ in Humanistic Sciences in the Field of Pedagogy, Assistant Professor (The Faculty of Education, the Institute of Social Prevention and Resocialization Jesuit University Ignatianum in Krakow, Poland) basiniaewp.pl

\title{
THE DIGITAL GENERATION OF CHILDREN AND ADOLESCENTS IN FACE OF INTERNET DANGERS
}

The dynamic development of digital media and the tools which create the world of new technologies influence their users' social and cultural transformations on a global scale. Undoubtedly, cyberspace enriches educational, upbringing and socializing opportunities of digital natives, that is children and adolescents who have grown up in the media space. The apparent usefulness of the Internet should not, however, lull parents' and teachers' vigilance, as it is potentially a highly dangerous tool due to its telepresence and the fact that young people are immersed in it.

The aim of the article is to analyze online identity of the digital generation, that is young people who have grown up in a completely new reality, different from any other in the past, and who describe themselves as 'always connected'. Since in the postmodern world (also in cyberspace) constructing one's identity is an individual's task, it seems justified to outline selected Internet dangers, such as cyber violence, Internet pornography and Internet hate. In order to facilitate young people's healthy development, the article lists a handful of preventive measures to be introduced in basic rearing environments that is family and school.

Key words: the Internet, digital generation, online identity, cyber violence, Internet pornography, Internet hate.

\section{Barbara Adamczyk ${ }^{1}$}

Introduction. New information technologies, primarily associated with the Internet, are common, easy to use, fast, functional and efficient in spreading information. The Internet, a pull medium, has made it almost impossible for children, adolescents and adults to imagine life outside the virtual world. Cyberspace offers its residents a feeling of unrestricted freedom without any barriers, because it houses almost everything: communication, education, entertainment, online banking and shopping and running a company. Without going outside, one can buy virtually every single item: books, gadgets, jewellery, and the latest car brand. The Internet allows its users to meet new people and participate in online discussion forums, chat rooms and instant messengers ${ }^{2}$.

The development of the Internet will certainly continue to be as dynamic as before, and access to it will become even more common and widespread, which poses a great socio-cultural challenge, especially in the area of education and rearing. This area is of interest to researchers, teachers, educators, psychologists, sociologists and other specialists in the field. Theoreticians and practitioners focus not only on positive aspects of the cyber world, which is now believed to be an indispensable element of the upbringing environment of children and adolescents, but also on dangers connected with using the Internet. Parents and teachers are the ones who must not neglect these dangers. The aim of the article is to describe online identity of young users of electronic media (the digital generations) and to diagnose Internet dangers from the perspective of their dramatic consequences for healthy socialization of children and adolescents. These dangers are real, as young people treat the virtual world as their natural life environment.

\section{Online identity of the digital generation.}

An integral component of the discussion focusing on children's and adolescents' identity is connected with the development of communication technologies. This generation is said to inhabit the world of digital media, being born and raised in cyberspace; as such they are the most active Internet users. This relation is aptly defined by M. Skibińska: "it is a generation which does not remember times without the Internet, and that is why the cyber world is not an alternative reality for them but its natural part, and the screens of telecommunications

\footnotetext{
${ }^{1} \mathrm{PhD}$ in Pedagogy and BA in Catechetics. Assistant Professor in the Department of Social Prevention and Resocialization at Jesuit University Ignatianum in Krakow. Scientific interests: the phenomenon of street children in Poland and worldwide, street work as an interdisciplinary method of work in the street, resocialization dimensions of street pedagogy, resocialization in an open environment, social pathologies, resocialization institutions, volunteering, social help institutions and non-governmental institutions.

${ }_{2}$ Cf. P. Olejnik, Internet - niebezpieczeństwo dezintegracji osobowości dziecka?, in: Dziecko i media elektroniczne - nowy wymiar dzieciństwa. Komputer i Internet w życiu dziecka i obraz jego dzieciństwa, ed. J. Izdebska, T. Sosnowski, vol. 2, Trans Humana, Białystok 2005, p. 125.
} 
devices do not tell stories of the outside world but allow them to immerse themselves in its space" ${ }^{3}$. It is obvious that in this situation of dependence, online identities of young media users created by the Internet are not ultimate and shaped once and for all. Young people nowadays live in the multifaceted reality of the virtual world, which gives ground to J. Ellul's thesis about the advancement of technology which cannot be stopped because it $<$ irrevocably moves forward $>$ and $<$ is not static $>^{4}$ and $\mathrm{Z}$. Melosik's opinion of the functioning of the youth in pop culture in which there is no place for "monolithic identity construction" 5 .

Identity, as most concepts in social sciences, is an ambiguous category, interpreted differently by various disciplines of science depending on what they focus on. Identity can be understood as personal identity, social identity, group identity, cultural identity, or local identity. Etymological understanding of identity reaches back to a Latin word idem - the same. D. Barney claims that "identity acquires a meaning only when a relation is formed: when things are the same we say that they are identical" ${ }^{6}$. To describe the relation between the youth and cyberspace, one must mention entanglement of the digital generation in a postmodern type of identity, called online identity. The main features of this identity are: fluidity, randomness, changeability, and multifacetedness. It is worth quoting here the opinion of S. Turkle, an American sociologist and personality psychologist, who described young people's presence on the Internet as "gradual making oneself up [...], you are who you pretend to be $[\ldots]$, your identity on the computer is the sum of your distributed presence $[\ldots]^{77}$.

The scale and intensity with which children and adolescents use the Internet have given rise to a term describing them, i.e. the digital generation. It is also a basic theme of our reflection. S. Livingstone believes that the digital generation consists of young people who know the net very well and have had access to it since their youngest years ${ }^{8}$. They are people born either after 1995 or after 2000 (depending on a point of view). Subject literature uses different terms with reference to the digital generation, for example, Generation Z (Millenials), Google Generation, Generation Me, Generation of Narcissists, Always-On Generation, Net Generation, Head Down Generation, Smombi (smartphone users), Screenagers and Digital Natives. The theoretical construct of online identity of the digital generation of children and adolescents will be built on the basis of the most salient features of the selected terms listed above.

The terms 'head down' and 'smombi' (coming from smartphones and zombie) directly derive from smartphonification of our lives, which has taken place since the appearance of the first iPhone on the market in 2007. As a mobile device, a smartphone combines the functions of a mobile phone, an entertainment platform and an instant messenger. According to I. Czerska, the term 'head down generation' describes people with their heads down and eyes glued to the screens of their smartphones. Most of them are pupils and students who surf the net, play games and use various mobile applications'. The term 'smombi generation' underlines their alienation from the world around. Their socio-cultural functioning is described by M. A. Motyka in the following way: when smombies use their smartphones "at the same time they do other things, e.g. follow the crowd, cross the street, drive a car, ride a bike, move in a public space, gather (at the cinema, theatre, concert, church), attend family and social meetings (in restaurants, cafes, clubs), traverse corridors of educational institutions" $^{10}$. Performing several activities simultaneously and moving around in the real world constitute a threat for smombies and other people.

'Screenagers' ${ }^{11}$ is another term used to describe the digital generation of postmodern global teenagers. The basic mode of their communication with others is not face-to-face communication but the screens of their

\footnotetext{
${ }^{3}$ M. Skibińska, Czy pokolenia cyfrowe potrzebuja edukacji informacyjnej?, in: Edukacja a nowe technologie $w$ kulturze, informacji $i$ komunikacji, ed. D. Siemieniecka, Wydawnictwo Naukowe Uniwersytetu Mikołaja Kopernika, Toruń 2015, p. 52.

${ }^{4}$ Cf. J. Ellul, The Technological System, The Continuum Publishing Corporation, New York 1980, p. 193.

${ }^{5}$ Z. Melosik, Kultura popularna i tożsamość młodzieży. W niewoli władzy $i$ wolności, Oficyna Wydawnicza "Impuls", Kraków 2013, p. 340.

${ }^{6}$ D. Barney, Społeczeństwo sieci, transl. M. Fronia, Wydawnictwo Sic!, Warszawa 2008, p. 167.

${ }^{7}$ Cf. S. Turkle, Life on the Screen: Identity in the Age of the Internet, Simon and Schuster, New York, 1995 , p. 10 .

${ }^{8} \mathrm{Cf}$. S. Livingstone, Children's use of the internet: reflections on the emerging research agenda, "New media \& Society" 5 (2003), no. 2, p. 148.

9 Cf. I. Czerska, Pokolenie head down jako konsekwencja smartfonizacji spoleczeństwa, "Prace Naukowe Uniwersytetu Ekonomicznego we Wrocławiu" (2016), no. 459, p. 215.

${ }^{10}$ Cf. M. A. Motyka, Pokolenie smombie: charakterystyka i typologia, Przestrzeń Społeczna 15 (2018), no. 1, p. 174.

${ }_{11}$ See D. Rushkoff, Playing the Future. How Kid's Culture Can Teach Us to Thrive in an Age of Chaos, HarperCollins, New York 1996.
} 
laptops, iPods, or smartphones. A. Ogonowska ${ }^{12}$ points at several negative features of screenagers' online personality: 1) attention deficit disorder 2) superficial and volatile knowledge 3) sharing their private life online 4) treating relations with friends and acquaintances in the real and virtual worlds in an identical way 5) problems with linguistic and communicative competence (e.g. they cannot form correct sentences in their mother tongue and are unable to select information) and 6) average media competences. However, limiting the analysis of screenagers' online personality only to its negative aspects is a simplification, as it presents one-sided and subjective view. The digital generation also has positive features, described by an American researcher, M. Bauerlein in the following way: "Undoubtedly, young users have learnt thousands of new things. They download and send files, surf the net and discuss in chat rooms, write posts and design, yet they cannot analyse complex texts, remember facts, understand foreign policy decisions, draw conclusions from history, and write without spelling mistakes" ${ }^{13}$

'Digital natives' is another popular term used to describe online identity of young media users who were brought up with the new media. M. Prensky, an American media expert and computer games designer, was the first to use this term ${ }^{14}$. One of the most spectacular successes of modern digital technologies is their naturalness and integration, and these features are mentioned in M. Jędrzejko and D. Morańska's description of digital natives. In their definition: "digital technologies are their natural environment for socialization and social relations, and the level of <integration $>$ with them is so high that, when digital natives lose access to digital devices, they show signs of great emotional tension, have problems with performing tasks and difficulties in carrying on with their daily and educational duties. For this generation the virtual world is natural and indispensable"15.

It can be concluded that online identity of the digital generation of children and adolescents does not exist in the void of the social and educational discourse but has become a recognizable and important research area in subject literature. The image of typical representatives of this generation presented above should be complemented by a list of their characteristic features offered by D. Tapscott ${ }^{16}$, which includes: freedom, adjusting to one's needs, watchful observation, credibility, cooperation, entertainment, quick pace and innovation. Older generations base their perception of the young generation on these features, especially with reference to their media habits.

\section{Selected Internet dangers faced by the digital generation.}

Expansion and versatility of new information technologies have undoubtedly become an element of the contemporary world. It has happened because, with an a priori assumption that cyberspace complements the real world and following D. Tapscott's ideas, it is a fact that the web generation has come ${ }^{17}$. The claim that, on the one hand, the number of children and adolescents using new media is growing rapidly, and, on the other hand, that they are exposed to Internet dangers is not truism but a disturbing and worrying fact, which poses an educational challenge to parents and teachers. As experts such as Jacek Pyżalski, Józef Bednarek or Janusz Morbitzer emphasize, mass access to the Internet is connected with its dysfunctional use, potentially affecting users' cognitive, emotional and physical spheres. Children and adolescents who function within the virtual world and who are unaware of the dangers, fall victim to their excessive contact with the new media with its intentional criminal activity and all kinds of manipulation. Sometimes it is them who, consciously or not, create situations which are dangerous to themselves and others ${ }^{18}$. This article provides a short outline of three Internet dangers: cyber violence, Internet pornography and Internet hate.

\subsection{Cyber violence.}

Subject literature uses various terms to describe violence inflicted through communication technologies, such as cyber stalking, cyber harassment, electronic aggression, or electronic mobbing. The term 'cyber violence' seems to have a broader scope than other terms, and that is why it has become is a leading term in the article.

Cyber violence is a phenomenon particularly harmful to children and adolescents, due to its following features: anonymity, secrecy of online communication, invisible audiences, and permanent availability of

${ }^{12}$ Cf. A. Ogonowska, Ekranolatki między mediami. W stronę nowej psychologii mediów, Zeszyt Naukowy. Wyższa Szkoła Zarządzania i Bankowości (2016), no. 40, pp. 6-7.

${ }_{13}$ M. Bauerlein, The Dumbest Generation: How the Digital Age Stupefies Young Americans and Jeopardizes Our Future, Penguin Tarcher, New York, 2008, p. 201.

${ }^{14}$ See M. Prensky, Digital Natives, Digital Immigrants, On the Horizon 9 (2001), no. 5, pp. 1-6.

${ }^{15}$ Cf. M. Jędrzejko, D. Morańska, Cyfrowi Tubylcy (socjopedagogiczne aspekty nowych technologii cyfrowych), Oficyna Wydawnicza ASPRA-JR, Dąbrowa Górnicza-Warszawa 2013, p. 89.

16 Cf. D. Tapscott, Cyfrowa dorosłość. Jak pokolenie sieci zmienia nasz świat, transl. P. Cypryański, Wydawnictwo Akademickie i Profesjonalne, Warszawa 2010, p. 46.

${ }^{17}$ Cf. ibid., p. 47.

${ }^{18}$ Cf. D. Morańska, Kilka słów na wstępie, in: Patologie w cyberprzestrzeni. Profilaktyka zagrożeń medialnych, ed. D. Morańska, Wydawnictwo Wyższej Szkoły Biznesu, Dąbrowa Górnicza 2015, p. 7. 
victims. Everyone can become a perpetrator without coming into physical contact with a victim, as it is enough to have a mobile phone or a computer to bully or persecute others. One of the most common definitions of cyber violence describes it as "an aggressive activity of a person or a group of people who use modern communication technologies to repeatedly attack a victim who is unable to defend himself/herself for a long time" ${ }^{19}$. This definition contains at least three basic features of cyber violence: the perpetrator's intentional and frequently repeated activity, the perpetrator's dominance over a victim, and electronic media. The most popular communication channels used in cyberspace include electronic mail, chat rooms, instant messengers, websites, blogs, Internet newsletters, social networking sites, discussion groups, SMS and MMS. The phenomenon of cyber violence is characterized by various activities described as acts of violence, which, following American researchers R. M. Kowalski, S. P. Limber and P. W. Agatson, can be divided into: flaming, harassment, denigration, impersonation, outing, trickery and happy slapping ${ }^{20}$.

Cyber violence involving peers is a serious social problem that is intensifying. It was investigated in a study conducted in southern Poland (Podkarpackie Voivodeship) in 15 junior high schools covering a sample of 1178 students. Its results confirm the presence of cyber violence in schools. One third $(33,0 \%)$ of the respondents fell victim to unwanted films and photos, and one fifth $(21,7 \%)$ admitted that they were recipients of this kind of violence while using the Internet or their mobile phones, boys more often than girls $(24,4 \%$ and $19,1 \%$ respectively). The study also revealed that the most frequent acts of violence affecting the respondents were: obscene language $(48,7 \%)$, mockery $(37,3 \%)$, humiliation $(27,7 \%)$ and spreading compromising material $(26,1 \%)^{21}$.

\subsection{Internet pornography.}

With the assumption that using the Internet is nowadays an indispensable part of children's and adolescents' everyday life, Internet pornography is a serious danger. Ł. Wojtasik openly talks about almost unrestricted access of the digital generation to pornographic materials on the Internet and their pushy advertising by adults ${ }^{22}$. This calls for a question about the influence and consequences of such experiences on psychological, social and sexual spheres of young Internet users.

Pornography, including Internet pornography, is a highly controversial issue, controversy beginning with its definition and legal aspects and ending with its consequences. Difficulty ingrained with this topic results from transformations pornography has been undergoing for the last decades and the changing socio-cultural context of the contemporary world. Addressing these dilemmas, M. Filar does not attempt to define pornography as such but points at certain features which allow for determining whether given materials are of pornographic nature. These features include a) presenting sexual activities in a way which focuses solely on their technical aspects, disregarding intellectual and personal layers, and b) displaying human sex organs in their sexual functions, which boils down to showing only dehumanised sex technology ${ }^{23}$. It is worth adding here that these features are aimed at creating sexual arousal in at least some viewers, which means that pornographic contents are not neutral for their target audience.

In 2017 K. Makaruk, J. Włodarczyk and P. Michalski ${ }^{24}$ from Dajemy Dzieciom Siłę (We Give Children Strength) Foundation conducted a study investigating teenagers' exposure to pornography in 90 schools in Poland, which covered a representative sample of 3943 students aged 11-18. Their study revealed that as many as $43 \%$ of the respondents had contact with pornographic materials: boys more frequently than girls $(50 \%$ and $36 \%$, respectively) and adolescents (aged 15-16-55\%, aged 17-18-63\%) more frequently than younger children (aged 11-12 - 21\%, aged 13-14 - 36\%). As far as the content of pornographic materials was concerned, students were mostly exposed to photos and films showing naked people (69\%); $15 \%$ of respondents saw only such materials. Most of them additionally saw photos and films showing a sexual intercourse $(60 \%)$ and private parts $(54 \%)$. Every fifth respondent $(22 \%)$ at the age of $13-18$ watched sex involving violence or hurting someone. Boys saw such materials more frequently than girls (23\% and $19 \%$, respectively). According to $60 \%$ of the respondents aged $15-18$, pornography can be harmful: it is the opinion of $49 \%$ of boys and $70 \%$

19 J. Barlińska, A. Szuster, Cyberprzemoc. O zagrożeniach i szansach na ograniczenie zjawiska wśród adolescentów, Wydawnictwo Uniwersytetu Warszawskiego, Warszawa 2015, p. 14.

${ }^{20}$ Cf. R. M. Kowalski, S. P. Limber, P. W. Agatson, Cyberprzemoc wśród dzieci i młodzieży, transl. A. Wicher, Wydawnictwo Uniwersytetu Jagiellońskiego, Kraków 2019, p. 53.

${ }^{21}$ Cf. S. Rębisz, I. Sikora, K. Smoleń-Rębisz, Świadomość i skala zjawiska cyberprzemocy wśród młodzieży gimnazjalnej województwa podkarpackiego, "Edukacja - Technika - Informatyka" 21 (2017), no. 2, p. 235.

${ }^{22}$ Cf. Ł. Wojtasik, Pedofilia i pornografia $w$ Internecie - zagrożenia dla dzieci, "Dziecko Krzywdzone" 2 (2003), no. 1, p. 1.

${ }^{23}$ Cf. M. Filar, Pornografia. Studium z dziedziny polityki kryminalnej, Wydawnictwo Uniwersytetu Mikołaja Kopernika, Toruń 1977, p. 45.

${ }^{24}$ Cf. K. Makaruk, J. Włodarczyk, P. Michalski, Kontakt dzieci i młodzieży z pornografia. Raport z badań, Fundacja Dajemy Dzieciom Siłę, Warszawa 2017, pp. 10-14. 
of girls. The most frequently mentioned negative outcomes of watching pornography were: addiction $(47 \%)$, an unrealistic depiction of a sexual intercourse, often accompanied by violence (35\%), and the formation of unrealistic beliefs regarding a human body ( $34 \%)$.

\subsection{Internet hate.}

In the rapidly changing and highly technologized contemporary world, which allows for initiating and maintaining endless contacts online and remaining anonymous, hate speech has become a phenomenon whose frequency and intensity are growing all the time and whose form is becoming more and more refined and less subtle at the same time ${ }^{25}$. Internet hate as a kind of deviant behaviour of Internet communication is redolent with hate speech. It is a public message or an opinion marked with a hostile attitude towards the recipient in which its author "uses abusive language, contemptuously assesses various phenomena, insults interlocutors and other people, and is aggressive and full of hatred towards them" ${ }^{26}$. A hater expresses his opinions by posting negative comments directed at other users. He comments in order to offend, and his usual target are celebrities and public persons ${ }^{27}$. A hater picks up fights, insults others, tries to irritate people with his comments and posts, and hits the dislike button after watching a film or other recorded materials. Most frequently, the hater's hatred stems from his life failures or directly from malice or envy of someone else's achievements. Sometimes he is so determined to post a negative comment that he creates many accounts in various services in order to inflict the greatest pain to the author of the commented material or other Internet users ${ }^{28}$. What is most worrying is the fact that Internet hate also affects the digital generation of children and adolescents.

K. Gawrol ${ }^{29}$ reports the results of the study from 2014 conducted among 38 young people aged 12-18 and realized within the project $<$ Internet bez nienawiści> (The Internet without hatred). The study revealed that the respondents found the term 'Internet hate' quite natural. They defined it as <anonymous offence> (boy, 15) or $<$ various offensive texts $>$ (girl, 14). Their examples of Internet hate included negative comments posted under photographs, especially on Facebook, which often resulted in the removal of the photo, editing photos and uploading them on the net (often on pornographic websites), and sending unpleasant photos or vulgar films. They also listed using swear language on the net and quarrels between friends on social networking sites, during which both parties insult each other and reveal private information. The respondents mentioned so called 'hate pages', that is pages dedicated to mass criticism of a particular person; such pages can be found on Facebook and are usually directed against famous persons, but also, which is particularly worrying, against peers.

A study from 2017 conducted by Global Dignity (a public benefit organization) is worth mentioning here. It investigated the phenomenon of Internet hate among young people aged 12-24, and its results were published in a report entitled Wilki i owce w Internecie, czyli raport na temat hejtu wśród mlodzieży (Wolves and sheep on the Internet, that is a report on Internet hate among teenagers $)^{30}$. Firstly, there were twice as many 'recipients' of Internet hate than its 'senders' among the respondents. Every one in seven declared that hate was present in their everyday life: they both 'generated' hate and received hate. Every third respondent fell victim to haters although they did not 'produce' Internet hate themselves. Secondly, anger, agitation, and rage were named as dominating emotions leading to hate. Haters were convinced that their blunt comments or mems revealed the truth, and they were not inclined to apologize - only one in six admitted to saying sorry to a person they had wronged with their Internet hate.

\section{Instead of conclusions.}

The $21^{\text {st }}$ century is the period in which the digital generation of children and adolescents use information and communication technologies to an extent not even imagined before. This is a great challenge for people responsible for their education and upbringing that is teachers and parents. As A. Wrona aptly observed, they should not only possess basic and ordered knowledge of the essence of cyberspace, research and educational

\footnotetext{
${ }^{25}$ J. Pyżalski, Agresja elektroniczna dzieci i młodzieży - różne wymiary zjawiska, "Kwartalnik Dziecko Krzywdzone" 26 (2009), no. 1, p. 13.

26 M. Juza, Hejterstwo w komunikacji internetowej: charakterystyka zjawiska, przyczyny i sposoby przeciwdziałania, "Profilaktyka Społeczna i Resocjalizacja" (2015), no. 25, p. 27.

${ }^{27}$ Cf. M. Wawrzyniak, Hejtoholik, czyli jak zaszczepić się na hejt, nie wpaść w pulapkę obgadywania oraz nauczyć zarabiać się na tych, którzy Cię oczerniaja, Wydawnictwo Onepress, Gliwice 2015, pp. 35-36.

${ }^{28}$ Cf. K. Rosińska, Zjawisko hejtingu wśród mlodzieży oraz sposoby przeciwdziałania, "Kultura - Media Teologia" (2017), no. 29, p. 12.

${ }^{29}$ Cf. K. Gawrol, Hejt w internecie - analiza zjawiska, "Edukacja - Technika - Informatyka" 18 (2016), no. 4, pp. 306-307.

Cf. Global Dignity, Wilki $i$ owce $w$ Internecie, czyli raport na temat hejtu wśród mlodzieży, https://businessinsider.com.pl (accessed : 13.11.2018).
} 
possibilities it offers, but also dangers its young users face ${ }^{31}$.

Selected examples of dangers presented in the article - cyber violence, Internet pornography and Internet hate - confirm the presence of these phenomena in the web. From this perspective, children and adolescents do not have to make a conscious effort to encounter them - it is enough for them to press a button - for example, out of sheer boredom - in their smartphone or computer to find them in a dangerous virtual space. Obviously, it is not possible to eliminate Internet dangers, but it is should also be obvious that preventive measures should be introduced both at home and at school. Here are several suggestions of activities which can counteract drastic consequences of the dangers analyzed in the article:

1) At home: a) strengthening face to face communication between children and parents, b) paying attention to children's emotional needs, c) strengthening family ties, d) encouraging children's extracurricular interests, e) fulfilling basic family functions, and f) helping children face and solve their problems.

2) At school: a) upgrading teachers' qualifications in the area of benefits and dangers of cyberspace, b) introducing adequate media education, c) teaching students how to use new forms of communication safely, and d) teaching students how to make conscious and responsible choices while using and moving around the net.

\section{REFERENCES}

1. Barlińska J. Cyberprzemoc. O zagrożeniach i szansach na ograniczenie zjawiska wśród adolescentów / J. Barlińska, A. Szuster. - Wydawnictwo Uniwersytetu Warszawskiego ; Warszawa, 2015.

2. Barney D. Społeczeństwo sieci / D. Barney ; transl. M. Fronia. - Wydawnictwo Sic ; Warszawa 2008.

3. Bauerlein M. The Dumbest Generation: How the Digital Age Stupefies Young Americans and Jeopardizes Our Future / M. Bauerlein. - Penguin Tarcher, New York, 2008.

4. Czerska I. Pokolenie head down jako konsekwencja smartfonizacji społeczeństwa / I. Czerska // "Prace Naukowe Uniwersytetu Ekonomicznego we Wrocławiu", 2016. - No. 459. - Pp. 214-221.

5. Ellul J. The Technological System / J. Ellul. - The Continuum Publishing Corporation. - New York, 1980

6. Filar M. Pornografia. Studium z dziedziny polityki kryminalnej / M. Filar. - Wydawnictwo Uniwersytetu Mikołaja Kopernika, Toruń 1977.

7. Gawrol K. Hejt w internecie - analiza zjawiska / K. Gawrol. - "Edukacja - Technika - Informatyka" 18 (2016). No. 4. - Pp. 304-309.

8. Global Dignity Wilki i owce w Internecie, czyli raport na temat hejtu wśród młodzieży / Global Dignity. - Access mode : https://businessinsider.com.pl (accessed: 13.11.2018).

9. Jędrzejko M. Cyfrowi Tubylcy (socjopedagogiczne aspekty nowych technologii cyfrowych)/ M. Jędrzejko, D. Morańska. - Oficyna Wydawnicza ASPRA-JR, Dąbrowa Górnicza-Warszawa, 2013.

10. Juza M. Hejterstwo w komunikacji internetowej: charakterystyka zjawiska, przyczyny i sposoby przeciwdziałania / M. Juza // "Profilaktyka Społeczna i Resocjalizacja" (2015). - Nr 25. - Pp. 27-50.

11. Kowalski R. M. Cyberprzemoc wśród dzieci i młodzieży/ R. M. Kowalski, S. P. Limber, Agatson P. W. ; transl. A. Wicher. - Wydawnictwo Uniwersytetu Jagiellońskiego, Kraków 2019.

12. Livingstone S. Children's use of the internet: reflections on the emerging research agenda / S. Livingstone. - "New media \& Society" 5 (2003). - No. 2. - Pp. 147-166.

13. Makaruk K. Kontakt dzieci i młodzieży z pornografią / K. Makaruk, J. Włodarczyk, P. Michalski // Raport z badań. - Fundacja Dajemy Dzieciom Siłę, Warszawa 2017.

14. Melosik Z. Kultura popularna i tożsamość młodzieży / Z. Melosik // niewoli władzy i wolności. - Oficyna Wydawnicza "Impuls", Kraków 2013.

15. Morańska D. Kilka słów na wstępie/ D. Morańska // Patologie w cyberprzestrzeni. Profilaktyka zagrożeń medialnych ; ed. D. Morańska. - Wydawnictwo Wyższej Szkoły Biznesu, Dąbrowa Górnicza 2015. - Pp. 7-8.

16. Motyka M. A. Pokolenie smombie: charakterystyka i typologia / M. A. Motyka. - Przestrzeń Społeczna 15 (2018). No. 1. - Pp. 169-202.

17. Ogonowska A. Ekranolatki między mediami / A. Ogonowska // Stronę nowej psychologii mediów, Zeszyt Naukowy. - Wyższa Szkoła Zarządzania i Bankowości (2016). - No. 40. - Pp. 1-17.

18. Olejnik P. Internet - niebezpieczeństwo dezintegracji osobowości dziecka? / P. Olejnik // Dziecko i media elektroniczne - nowy wymiar dzieciństwa. Komputer i Internet w życiu dziecka i obraz jego dzieciństwa; ed. J. Izdebska, T. Sosnowski. - Vol. 2, Trans Humana, Białystok 2005. - Pp. 125-133.

19. Prensky M. Digital Natives, Digital Immigrants / M. Prensky. - On the Horizon 9 (2001). - No. 5. - Pp. 1-6.

20. Pyżalski J. Agresja elektroniczna dzieci i młodzieży - różne wymiary zjawiska / J. Pyżalski. - "Kwartalnik Dziecko Krzywdzone" 26 (2009). - No. 1. - Pp. 9-13.

21. Rębisz S. Świadomość i skala zjawiska cyberprzemocy wśród młodzieży gimnazjalnej województwa podkarpackiego / S. Rębisz, I. Sikora, K. Smoleń-Rębisz. - "Edukacja - Technika - Informatyka" 21 (2017). - No. 2. - Pp. 231-238.

22. Rosińska K. Zjawisko hejtingu wśród młodzieży oraz sposoby przeciwdziałania / K. Rosińska // "Kultura - Media Teologia", 2017. - No. 29. - Pp. 9-23.

${ }^{31}$ Cf. A. Wrona, Ciemna strona sieci - zagrożenia internetowe oraz ich konsekwencje dla uczniów, in: Zagrożenia cyberprzestrzeni i świata wirtualnego, ed. J. Bednarek, A. Andrzejewska, Difin SA, Warszawa 2014, p. 95. 
23. Rushkoff D. Playing the Future. How Kid's Culture Can Teach Us to Thrive in an Age of Chaos / D. Rushkoff. HarperCollins, New York 1996.

24. Skibińska M. Czy pokolenia cyfrowe potrzebują edukacji informacyjnej? / M. Skibińska // Edukacja a nowe technologie w kulturze, informacji i komunikacji ; ed. D. Siemieniecka. - Wydawnictwo Naukowe Uniwersytetu Mikołaja Kopernika, Torun 2015. - Pp. 49-67.

25. Tapscott D. Cyfrowa dorosłość. Jak pokolenie sieci zmienia nasz świat / D. Tapscott ; transl. P. Cypryański. Wydawnictwo Akademickie i Profesjonalne, Warszawa 2010.

26. Turkle S. Life on the Screen : Identity in the Age of the Internet/ S. Turkle // Simon and Schuster. - New York, 1995.

27. Wawrzyniak M. Hejtoholik, czyli jak zaszczepić się na hejt, nie wpaść w pułapkę obgadywania oraz nauczyć zarabiać się na tych, którzy Cię oczerniają / M. Wawrzyniak. - Wydawnictwo Onepress, Gliwice 2015.

28. Wojtasik Ł. Pedofilia i pornografia w Internecie - zagrożenia dla dzieci, "Dziecko Krzywdzone" 2 (2003). - No. 1. Pp. 1-5.

29. Wrona A. Ciemna strona sieci - zagrożenia internetowe oraz ich konsekwencje dla uczniów, in: Zagrożenia cyberprzestrzeni i świata wirtualnego / A. Wrona; ed. J. Bednarek, A. Andrzejewska, Difin SA. - Warszawa 2014. Pp. 82-97.

\section{Адамчик Б. Циррова генерація дітей та підлітків в умовах небезпеки Інтернету.}

Динамічний розвиток ичифрових засобів масової інформації та інструменти, які створюють світ нових технологій, впливають на сочіальні та культурні перетворення своїх користувачів у глобальному масмтабі. Безумовно, кіберпростір збагачує освітні, виховні можливості, а також можливості спілкування циифрового покоління, тобто дітей та підлітків, які виросли в медіа-просторі. Очевидна користь Інтернету, однак, вона не повинна приспати пильність батьків та вчителів, оскільки потенційно є надзвичайно небезпечним інструментом.

Метою статті є аналіз онлайн-ідентичності цифрового покоління, тобто молодих людей, які виросли в абсолютно новій реальності, відрізняючись від будь-якого іншого в минулому, і які описують себе як

тих, щзо "завжди на зв'язку". Оскільки в постмодерністському світі (також у кіберпросторі) конструювання особистості є завданням індивіда, то виправдано окреслити вибрані Інтернетнебезпеки, такі як кібер-насильство, інтернет-порнографія та ненависть до Інтернету. 3 метою сприяння здоровому розвитку молоді, в статті перераховано кілька профілактичних заходів, які слід запровадити в основних середовищах виховання - сім'ї та школі.

Ключові слова: Інтернет, цүифрове покоління, онлайн-ідентифікація, кібер-насильство, інтернетпорнографія, ненависть до Інтернету.

\section{Адамчик Б. Цирровая генерация детей и подростков в условиях опасности Интернета.}

Динамическое развитие цифровых средств массовой информации, а также инструментов, которые создают мир новых технологий, влияют на сочиальные и культурные преобразования своих пользователей в глобальном масштабе. Безусловно, киберпространство обогащает образовательные, воспитательные возможности, а также возможности общения цииррового поколения, а именно детей и подростков, выросших в медиа-пространстве. Очевидна польза Интернета, однако, она не должна усыпить бдительность родителей и учителей, поскольку является чрезвычайно опасным инструментом. Целью статьи является анализ онлайн-идентичности цицррового поколения, а именно молодых людей, выросших в совершенно новой реальности, которое отличается от любого другого поколения в прошлом, и которые описывают себя как те, что "всегда на связи". Поскольку в постмодернистском мире (также в киберпространстве) конструирование личности является задачей индивида, то оправдано вылелить выбранные Интернет-опасности, такие, как кибер-насилие, интернет-порнография и ненависть к Интернету. В иелях содействия здоровому развитию молодежи, 8 статье перечислены несколько профилактических мероприятий, которые следует ввести в основных средах воспитания - семье и школе.

Ключевые слова: Интернет, ичифровое поколение, онлайн-идентификаияя, кибер-насилие, интернетпорнография, ненависть к Интернету. 